\title{
BANKING SECTOR LIBERALIZATION AND ECONOMIC GROWTH: CASE STUDY OF PAKISTAN
}

\author{
Najia SAQIB \\ Business Administration Department, Prince Sultan University, \\ P.O.Box No. 66833 Rafha Street, Riyadh 11586 Saudi Arabia \\ E-mails:dr.najiasaqib@gmail.com,nsaqib@psu.edu.sa
}

Received 20 March 2013; accepted 09 May 2013

\begin{abstract}
Economic theory suggests that sound and efficient financial systems channel capitals to its most productive uses are beneficial for economic growth. Sound and efficient financial systems are especially important for sustaining growth in developing countries. This paper examines the impact of banking sector liberalization on long-term economic growth in Pakistan by using a time series data for the period 1971-2011. The results show that there exist a significant positive long run relationship between banking sector development and economic growth in the country. The sensitivity analysis also shows that the relationship remain positive and significant no matter what combination of the omitted variables are used in the basic model. Thus, our findings support the core idea that banking sector development stimulates long term economic growth in a country.
\end{abstract}

Keywords: financial development, financial deepening, financial efficiency, financial liberalization, economic growth, Time-series models, banking sector.

JEL Classification: E44, O16, G14, O40, O11, C22, G21.

\section{Introduction}

The role of banking sector is more crucial in developing countries as the financial sector provides the financial services to the rest of the economy. The important role of the banking sector in all economies is to channel resources from primary savers to investment opportunities. Therefore, efficient banking system facilitates better mobilization and use of resources and thus, accelerates the process of economic growth.

As banking sector plays a crucial role in the economic development, most governments in developing countries intervened to the banking sector to achieve the economic growth. Common types of government intervention to the domestic financial sector are interest rate ceilings, selective credit allocation, market-entry regulation, government ownership, and capital flows. Restrictions and control on bank behavior imposed by governments often results in negative real interest rate, high inflation, and less supply of loanable funds and excess demand for credit. Many studies showed that government's control and intervention in the banking system limits the operation of market mecha- 
nisms, led to financial repression, and slower the economic development. For these reasons, governments became increasingly aware that government's intervention in the financial system has failed. As a result, the restrictions had been relaxed in developing countries during the 1970s and 1980s. In order to overcome the problems and spur growth, the government embarked on a wide range of structural adjustment program and banking sector reforms were an important component of this program ${ }^{1}$.

Pakistan is the late mover in the process of banking sector reform. They started to liberalize their banking sector in the late 1980s and early 1990s, following the economic reform. Prior to this, in the planned economies, the banking systems were under the control of the governments and mono banking system took the leading role for the development of the financial sector.

The first stage of reform package split the mono banking system into two-tier banking system, thus separating the central bank's functions. Therefore, the state owned banks became the state commercial banks. Then, private owned domestic commercial banks, foreign banks, foreign bank representative offices, and other financial institutions were allowed to participate in the financial sector. Gradually, state ownership is being replaced by private ownership.

To promote intermediation and to attract funds held abroad by Pakistani nationals, the residents were allowed to open foreign currency accounts with banks in Pakistan, which were freely transferable abroad. Full convertibility of the Pak-rupee was established on current international transactions. The establishment of an inter-bank foreign exchange market also marked an important step towards decentralizing the management of foreign exchange and allowing market forces to play greater role in exchange rate determination. These banking sector reforms have a positive impact on the indicators of financial deepening in the country as shown in Table 1.

Table 1. Banking liberalization and economic growth indicators (percent)

\begin{tabular}{lccccc}
\hline & $1971-1980$ & $1981-1990$ & $1991-2000$ & $2001-2006$ & 2007-2011 \\
\hline Financial Depth-1 & 40.00 & 41.19 & 39.93 & 43.40 & 45.18 \\
\hline Financial Depth-2 & 36.75 & 32.88 & 39.40 & 42.25 & 50.25 \\
\hline Currency to GDP & 8.64 & 11.60 & 10.42 & 10.64 & 10.50 \\
\hline Currency to M2 & 28.38 & 32.04 & 26.33 & 23.40 & 21.30 \\
\hline Private Credit to GDP & 16.91 & 19.03 & 20.77 & 23.93 & 29.73 \\
\hline Real GDP growth & 5.60 & 6.14 & 4.41 & 5.49 & 3.99 \\
\hline Real Per capita Income growth & 2.44 & 3.03 & 2.33 & 3.36 & 3.10 \\
\hline
\end{tabular}

Note: Financial depth-1 measured as broad money to one year lagged GDP and financial depth-2 measured as bank deposits to one year lagged GDP.

\footnotetext{
${ }^{1}$ These reforms covered financial liberalization, institutional strengthening, domestic debt, monetary management, banking law, foreign exchange and capital market.
} 
Table 1 shows that financial depth has steadily increased in the country, representing a steady development in the banking sector. The currency to GDP ratio and currency to broad money (M2) has also increased over time, representing a greater degree of monetization in the country. The private sector credit to GDP ratio has also increased in the country reflecting a proper allocation of funds by banking sector. The data come from the various issues of the State Bank of Pakistan's Statistical Periodicals.

The above banking sector development in the country generates an interest to study the link between the banking sector's development and economic growth in the country. A review of the existing literature shows that most of the previous studies into the relationship between banking sector development and economic growth are cross country in nature. The use of the cross-country regression is not without problems, since they do not properly account for the time dimension. Moreover the cross-country estimates can give a wrong impression of the impact of banking sector development on economic growth since they assume that different countries in the model are homogenous entities. Since countries may differ greatly with respect to institutions and economic policies used, results may not be true for a specific country.

The shortcomings of the cross-country/panel estimators have prompted a number of researchers to rely on time-series method to examine the finance-growth nexus based on the data of individual countries (Neusser et al. 1998; Rousseau, Watchel 1998; Arestis et al. 2001). As argued by Arestis et al. (2001: 17), 'time series methods can provide useful insights into differences of this financial development and economic growth relationship across countries and may illuminate important details that are hidden in averaged-out results. However, no attempt has been made to use the same technique to investigate the channels through which financial development affects economic growth in the U.S ${ }^{2}$. This study attempts to fill in this gap.

The rest of the paper is structured as follows. Section 1 gives a brief review the theoretical background and empirical studies. Section 2 discusses the modeling framework and estimation results. Section 3 performs the sensitivity analysis. Final section concludes the study and discusses the policy implications.

\section{Literature review}

The role of banking sector development in economic growth has been examined both theoretically and empirically in the recent literature. However, this debate is not new in the development economics literature and can be traced back to Schumpeter's (1911) Theory of Economic Development. Since then this issue had been extensively studied by Goldsmith (1969), McKinnon (1973) and Shaw (1973) and others, who produced

\footnotetext{
${ }^{2}$ An exception to this generalization is Neusser et al. (1998), which, based on time-series data, studies the effect of financial development on economic growth in several OECD countries including the U.S. However, it is limited to the impact of financial development on the growth of the manufacturing sector and does not address the question whether financial development promotes growth by increasing the level of investment.
} 
considerable evidence that banking sector development correlates with economic growth. They consider that all forms of public control on the financial market achieved by quantitative instruments (directed credits for selected strategic sectors, high reserve ratios) or price instruments (interest rate ceiling) generate a financial repression situation characterized by negative real interest rates, low levels of savings, investments and therefore growth. Consequently, they have underscored the need for financial liberalization, the elimination of all forms of public intervention and freeing the real interest rate. But their work though insightful, lacked analytical foundation. The recent revival of interest in the link between banking sector development and growth stems mainly from the insights and techniques of endogenous growth models. Since economic growth may come from the growth in the factors of production or increases in the efficiency with which those factors are used. Banking sector development basically affects economic growth by increasing the saving rate, thereby raising the level of investment. Furthermore, by efficiently allocating the available resources, it increases the productivity of investment ${ }^{3}$.

Rapid changes in financial service industries make it important to determine the efficiency of financial institutions (Berger et al. 1993). Banks play an important role in the financial markets of the developing countries and it is very important to evaluate whether banks operate efficiently or not. There are many research studies that try to look into the efficiency of banks operating within a country and across the countries. These studies can be differentiated on the basis of used methodologies, considered variable, type and number of banks included in the sample.

Many theoretical and empirical studies indicate that in the development of the economy, banking sector plays an important role. A number of economists linked the efficiency and development of the financial institutions with economic growth and also established channels through which the financial system affects economic growth (McKinnon 1973; Levine 1997; Tsuru 2000). A positive relationship between financial sector development and economic growth was established by economists in various empirical studies (Goldsmith 1969; King et al. 1993a, 1993b; Levine et al. 1999; Khan, Senhadji 2000).

Aly et al. (1990) analyzed technical, scale and allocative efficiencies in U.S. baking by using non parametric frontier approach on a sample of 322 independent banks. According to them, major contributor to the low score of overall efficiency was technical inefficiency in the banking units as compared to allocative inefficiency.

Altunbas et al. (1994) justified the privatization of Turkish public banks on the grounds of efficiency improvement. For the study, they used the stochastic cost techniques for the analysis of performance difference between public and private banks. After analysis, they found a statistically non significant inefficiency difference between private and public banks. So on the basis of statistically insignificant inefficiency difference; they favored the privatization of public banks.

Ayadi (1996) measured the bank performance in Nigeria by applying data envelopment analysis to ten banks by using financial data from 1991-1994. They used interest paid

\footnotetext{
${ }^{3}$ See, Pagano (1993) and Levine (1997) for a comprehensive survey of the literature.
} 
on deposits, total expenses and total deposits as inputs while total loans, interest and non-interest incomes were considered as outputs. They reported that banks in existence for long period of time are relatively efficient than other banks in the sample and banks having poor management showed bad performance and is key determinant of the bad performance of banks in Nigeria.

Chang et al. (1998) used translog formulation of stochastic cost frontier method to estimate the cost inefficiency scores. For this purpose, they used foreign owned multinational banks and local US banks. The banking data of period 1984-1989 were used for the study. From the study they found that foreign owned banks operating in US were significantly less efficient than their local counterparts.

Mendes and Joao (1999) used the stochastic cost frontier methodology to study the performance of 221 Portuguese banks from 1990 to 1995. They found that the increased competition in the banking sector did not improve the cost efficiency of banks. Similarly no clear existence of predicable association between size and cost efficiency was found in the banks.

$\mathrm{Xu}(2000)$ used a multivariate vector autoregressive approach to examine the effects of permanent financial development on domestic investment and output in 41 countries between 1960 and 1993. The results showed that financial development is important to GDP growth and that domestic investment is an important channel through which financial development affects economic growth. Furthermore, many countries were able to turn the short-term negative effects to long term positive effects, and all these results were robust.

Ataullah et al. (2004) made a comparative analysis of commercial banks in India and Pakistan during 1988-1998. To measure efficiency, they used Data Envelopment Analysis and employed two input-output specifications for efficiency measurement. In one specification (loan based model), operating and interest expenses were used as inputs while loans and advances (along investment) were considered as outputs of the commercial bank. In second specification (income based model), operating and interest expenses were considered as inputs while interest and non interest income worked as outputs of the commercial bank. They decomposed technical efficiency into pure technical efficiency and scale efficiency. From analysis, they found that the efficiency score in loan based model was much higher as compared to the income based model. At the same time, results also indicated the presence of space of improvement in the efficiency of banks in these countries.

Khan et al. (2005) tested the relationship between financial development and economic growth for Pakistan over the period 1971-2004, using Autoregressive Distributed Lag (ARDL) technique. The results of the study showed that in the long-run financial depth and real interest rate exert positive impact on economic growth. However, the relationship between growth and financial development is though positive but remained insignificant in the short-run. They concluded that growth is an outcome of financial development. 
Burki and Niazi (2006) analyzed the impact of financial reforms on the efficiency of state, private and foreign banks of Pakistan by using data of 40 banks for the period 1991-2000. They used DEA to estimate the efficient frontier by using loans and advances, investments and contra accounts as outputs of the bank and labor, physical capital, operating cost and financial capital as input of the bank. By using respective year's data about inputs and outputs of the banks, efficiency frontier was estimated for that year and for each year, banks cost, allocative, technical, pure technical and scale efficiency was computed. To study the impact of banks size, interest income to earning assets, loans to deposit ratio, foreign and private ownership on the estimated efficiency scores, they used tobit model and found positive impact of all these variables on the estimated efficiency scores.

Waheed and Younus (2010) analysed the effects of financial sector's development and financial sector's efficiency on economic growth of a group of selected developing and developed countries using a cross-country data averaged over the period 2001-2005. The results show that the effect of financial sector's development and financial sector's efficiency on economic growth is significantly positive for a full sample of 98 developing and developed countries. For a sample of 64 developing countries the effect of financial sector's development and financial sector's efficiency is also positive and highly significant, however, for a sample of 26 developed countries the effect of financial sector's development is significantly positive but the effect of financial sector's efficiency is positive but statistically insignificant. The sensitivity analysis also shows that the relationship remain positive and significant no matter what combination of the omitted variables are used in the basic model. Thus, our findings support the core idea that financial sector's development and financial sector's efficiency stimulates economic growth.

Adam (2011) investigated the relationship between financial liberalization and economic growth for Ghana economy over the period 1970-2007, using the Johansen Cointegration test and Granger-Causality tests. The results showed that there is a positive relationship between growth and standard of living, though it is disproportionate. Also, it provides evidence that there exist a positive long-run relationship between financial liberalization and growth. This means that Ghana's financial liberalization has contributed positively towards its economic growth.

Odhiambo (2011) analyses the impact of financial liberalization in developing countries with specific reference to Zambia, South Africa, Tanzania and Lesotho. The results showed that findings show that although financial liberalization leads to financial development in all the study countries, it Granger-causes economic growth only in Zambia. In other words, in the remaining three countries, namely, South Africa, Tanzania, and Lesotho, it is the economic growth which encourages the development of the financial sector. This finding shows that the relationship between financial liberalization and economic growth is at best ambiguous, and may be sensitive to a country's level of financial development.

Campos et al. (2012) analyzed the impact of financial liberalization on economic growth for Argentina over the period from 1896-2000 by using an econometric methodology by $\mathrm{ARCH}$ technique. The main results show that the long-run effect of financial liberaliza- 
tion on economic growth is positive while the short-run effect is negative, although substantially smaller. The study also concluded that financial development affects growth only directly, that is, not through growth volatility.

Sulaiman et al. (2012) investigated the effect of financial liberalization on the economic growth in Nigeria using financial deepening (M2/GDP) and degree of openness as financial liberalization indices, the findings showed that there exists a long-run equilibrium relationship among the variables. The study concluded that financial liberalization has a growth-stimulating effect on Nigeria and recommended that economic stability should either be maintained or pursued before implementing any form of financial liberalization measures and the regulatory and supervisory framework for the financial sector should be strengthened.

Bouzid (2012) tested for empirical evidence to verify the complementarity hypothesis for the Arabic Maghrebean countries from 1973 to 2003. The money demand and investment function were estimated in static long-run formulations (cointegration regression) as well as in the dynamic formulation (VECM). The coefficient of the investment ratio in the money demand function (M2/P) was positive only for Algeria.

Owusu and Odhiambo (2013) tested the impact of financial liberalization and economic growth in Nigeria over the period from 1981-2012 by using the McKinnonShaw framework. The result shows that financial liberalization and private investment have significant effects on economic growth and study also conclude that the monetary authorities and policy maker in Nigeria need to support the liberalization process by financial sector reforms so benefits of liberalization is maximized. Hye and Wizarat (2013) also investigate the impact of financial liberalization on economic growth for Pakistan economy over the period of 1971-2007 by using Auto-Regressive Distributed Lag (ARDL) technique. The main results show that there is a positive relationship in between financial liberalization and economic growth in the short run and insignificant in the long run.

Greenwood et al. (2013) examined the impact of financial development on economic development using the cross-country analysis. The findings of this study show that financial development explains about 23 percent of cross-country dispersion in output. The analysis suggests that financial intermediation is important for economic development.

Hsueh et al. (2013) also analysed the causality between financial development and economic growth and found that the direction of causality between financial development and economic growth is sensitive to the financial development variables. The findings of this study support the supply-leading hypothesis, as many financial development variables lead economic growth in some of the sample countries.

Bumann et al. (2013) analysed the relationship between financial liberalization and economic and found that there was a positive effect of financial liberalization on growth, however, the significance of this effect was only weak. P. K. Narayan and S. Narayan (2013) also observed the impact of the financial system on economic growth and findings of this study are that bank credit has a negative statistically significant effect on the economic growth. 
Overall, recent empirical evidence from time-series, cross-country and panel studies suggests that financial liberalization is an important determinant of economic growth. However, the impact may be nonlinear even the direction of causality have remained unresolved in both theory and empirics.

\section{Modeling framework}

Following the standard growth theories the log of real GDP per capita (Y) is taken as the proxy for economic growth. The data on physical capital stock is not available for Pakistan; study therefore, used gross fixed capital formation as a ratio of GDP (GFCF) to proxy this variable. Financial sector development is represented by financial depth which is measured as broad money to one year lagged GDP (M2). Other growth determining factors such as, government expenditure on health (HEL) and government expenditure on education (EDU) both as a ratio of GDP - proxy variables for human capital, a trade to GDP ratio as a measure of openness (OPE), foreign direct investment (FDI) as a ratio of GDP, are also considered in the analysis.

Human capital is an important variable that is commonly added in these types of studies see Levine (1997). Levine and Renelt (1992) found in their study that trade liberalization and growth relations may occur through investment, and trade openness may provide greater access to investment goods. Levine and Zervos (1998) show that stock markets and banks provide different services, but stock market liquidity and banking development positively predict growth and capital accumulation. Thus, based on the theoretical discussion, empirical studies, data availability and the need to conserve degrees of freedom, only three variables are chosen for our basic model to explain the variation in per capita income ${ }^{4}$. These are defined below:

$$
Y=\alpha_{0}+\alpha_{1} \cdot \mathrm{GFCF}+\alpha_{2} \cdot M_{2}+\alpha_{3} \cdot \mathrm{HEL}+\varepsilon_{4},
$$

where $\varepsilon_{4}$ is the error term. The data that have been used in this analysis are annual, covering the period from 1971 to 2012 . This is the latest period up to which all data are available in complete form. The data come from the various issues of the Government of Pakistan's Economic Survey.

Before proceeding further it is imperative to ensure that the underlying data are stationary. For this Augmented Dickey-Fuller (ADF) test an extension of the Dickey-Fuller (DF) method see Dickey and Fuller (1981) can be is used. However, this test assumes that the errors are statistically independent and have a constant variance. To circumvent these limiting assumptions, Phillips and Perron (1988) developed a generalization of the Dickey-Fuller test, which is also applied here ${ }^{5}$ The ADF and PP tests results are reported in Table 2, where study can see that all variables are non-stationary at levels, but stationary at first difference.

Since study has concluded that variables in the system are I(1), the OLS regression results of the equation (1) are reported in Table 3.

\footnotetext{
${ }^{4}$ The other variables shall be used for sensitivity analysis.

${ }^{5}$ The Phillips-Perron (PP) method has also been added to test the robustness of our results.
} 
Table 2. Results of stationarity test with and without time trend

\begin{tabular}{lcccccccc}
\hline & \multicolumn{3}{c}{ Augmented Dickey-Fuller Test (ADF) } & \multicolumn{3}{c}{$\begin{array}{c}\text { Phillips-Perron Test } \\
\text { (PP) }\end{array}$} \\
\cline { 2 - 11 } & \multicolumn{2}{c}{$\mathrm{I}(0)$} & \multicolumn{2}{c}{$\mathrm{I}(1)$} & \multicolumn{2}{c}{$\mathrm{I}(0)$} & \multicolumn{2}{c}{$\mathrm{I}(1)$} \\
\cline { 2 - 10 } & $\mathrm{C}$ & $\mathrm{C} \& \mathrm{~T}$ & $\mathrm{C}$ & $\mathrm{C} \& \mathrm{~T}$ & $\mathrm{C}$ & $\mathrm{C} \& \mathrm{~T}$ & $\mathrm{C}$ & $\mathrm{C} \& \mathrm{~T}$ \\
\hline $\mathrm{Y}$ & 0.51 & -2.15 & -4.48 & -4.44 & 0.42 & -1.62 & -4.44 & -4.40 \\
\hline GFCF & -1.74 & -3.00 & -5.30 & -5.21 & -1.26 & -2.16 & -5.39 & -5.28 \\
\hline M2 & -1.68 & -2.99 & -4.66 & -4.80 & -0.98 & -2.91 & -4.31 & -4.56 \\
\hline HEL & -2.67 & -2.73 & -6.09 & -6.07 & -2.67 & -2.38 & -6.77 & -7.47 \\
\hline EDU & -1.878 & -1.555 & -5.852 & -5.871 & -1.879 & -1.581 & -5.852 & -5.871 \\
\hline OPE & -1.582 & -2.790 & -6.026 & -5.937 & -1.068 & -2.408 & -6.926 & -6.680 \\
\hline FDI & 0.152 & -2.599 & -5.044 & -5.325 & -0.123 & -2.747 & -5.012 & -5.314 \\
\hline
\end{tabular}

Note: McKinnon critical values for intercept $(\mathrm{C}) ; 1 \%$ level $=-3.6394,5 \%$ level $=-2.9511$, and for intercept $\&$ trend $(C \& T) ; 1 \%$ level $=-4.2529,5 \%$ level $=-3.5485$. Lag length in all cases is one.

Table 3. Banking sector development and economic growth

\begin{tabular}{lccc}
\hline & Coefficient & t-stats & Probability \\
\hline Constant & 7.005 & 10.470 & 0.000 \\
\hline Investment GDP ratio & 0.156 & 2.262 & 0.043 \\
\hline Health expenditure ratio & 0.166 & 8.327 & 0.000 \\
\hline Financial depth & 0.178 & 6.489 & 0.000 \\
\hline Adjusted-R & 0.997 & - & - \\
\hline Durbin Watson stat. & 2.076 & - & - \\
\hline F-statistics & 1786.912 & - & 0.000 \\
\hline
\end{tabular}

It is clear from Table 3 that financial depth has significant positive impact on economic growth in Pakistan. However, since all the variables have a unit root, the existence of a co-integrating vector is a necessary condition for any sensible interpretation of the results. The fundamental aim of co-integration analysis is to detect any common stochastic trends in the data and to use these common trends for a dynamic analysis. So co-integration tests are performed to test for the presence of a long-run relationship between financial development and economic growth. The OLS regression result, which is the first step of Engle and Granger (1987) procedure, is shown in Table 4. The results show that the long run coefficient of financial depth is positive and highly significant. However, if and only if, this exist a co-integration, then these will be the valid long run estimates. To confirm this, study goes to the second step of the Engle-Granger procedure and check the stationarity of the residuals using ADF test. According to the Engle and Granger approach, if the error term is a stationary process or I(0), then cointegration exists. In other words, although individually the variables are non-stationary, if residuals are found to be stationary the regression is a co-integrating regression. 
Table 4. Residuals stationarity test

\begin{tabular}{lcc}
\hline & With intercept & With intercept \& trend \\
\hline ADF test statistics & -3.585 & -3.885 \\
\hline Probability & 0.011 & 0.024 \\
\hline
\end{tabular}

Note: McKinnon critical values for intercept $(\mathrm{C}) ; 1 \%$ level $=-3.6394,5 \%$ level $=-2.9511$, and intercept $\&$ trend $(\mathrm{C} \& \mathrm{~T}) ; 1 \%$ level $=-4.2529,5 \%$ level $=-3.5485$.

Table 4 shows that the ADF statistic is smaller than the critical value in all cases therefore the error term is stationary at a high significance level. Hence, study concludes that banking sector development is positively related with economic growth in the long run. Next study presents further evidence supporting co-integration using the technique developed by Johansen (1988) and extended by Johansen and Juselius (1990) that proposed a maximum-likelihood testing procedure for the number of co-integrating vectors that also include testing procedures for linear restrictions on the co-integrating parameters. Johansen likelihood procedure for the test of co-integration consists of the trace test and the maximum eigenvalue test. The trace statistic tests the null hypothesis that the number of co-integrating vectors are less than or equal to $r$ against a general alternative and the maximum eigenvalue statistic tests the null hypothesis that the number of co-integrating vectors are $\mathrm{r}$ against an alternative $r+1$. With $\mathrm{n}$ variables, the number of co-integrating vectors $r$ can at maximum be $n-1$. The results of co-integration test are shown in Table 5.

Table 5. Co-integration test results

\begin{tabular}{lcccc}
\hline $\begin{array}{c}\text { Hypothesized } \\
\text { no. of CE(s) }\end{array}$ & $\begin{array}{c}\text { Trace } \\
\text { statistics }\end{array}$ & $\begin{array}{c}5 \text { percent } \\
\text { critical values }\end{array}$ & $\begin{array}{c}\text { Max-eigenvalue } \\
\text { statistics }\end{array}$ & $\begin{array}{c}5 \text { percent } \\
\text { critical values }\end{array}$ \\
\hline None & 52.510 & 47.21 & 27.715 & 27.07 \\
\hline At most 1 & 24.795 & 29.68 & 19.741 & 20.97 \\
\hline At most 2 & 5.054 & 15.41 & 3.980 & 14.07 \\
\hline At most 3 $(r=3)$ & 1.074 & 3.76 & 1.075 & 3.76 \\
\hline
\end{tabular}

The co-integration test results suggest that there are linkages between all four variables, per capita income, investment, financial depth and indicator of human capital (Govt. expenditure on education). According to the maximum eigenvalue test and the trace test, the null hypothesis of no co-integration $(r=0)$ is rejected at 5 percent level of significance and alternative hypothesis $(r=1)$ is accepted showing that there is only one co-integrating vector of the relation between banking sector development and economic growth. The presence of one co-integrating vector indicates a stable long-run relationship between banking sector development and economic growth ${ }^{6}$.

\footnotetext{
${ }^{6}$ The authors' also tried the error correction model to test the short run relationship between financial development and economic growth but the results were insignificant.
} 


\section{Sensitivity analysis}

The above discussion is based on the orthogonalization strategy that seems the most meaningful based on a priori theoretical grounds. Since many factors are associated with economic growth, the empirical results on the relationship between one factor and economic growth is not always robust. Therefore, it is necessary to examine the robustness of the results reported in the Table 3. The question of how much confidence could be placed on the conclusions was addressed by Levine and Renelt (1992) that used a modified version of the Extreme Bond Analysis (EBA) originally developed by Leamer (1985). Such kind of analysis is important in cross country regression, however, for the present case, a slightly modified version of EBA approach is used. Consider the following model:

$$
Y_{t}=\beta_{0}+\beta_{1} \cdot I_{t}+\beta_{2} \cdot M_{t}+\beta_{3} \cdot Z_{t}+\xi_{t},
$$

where $Y$ is the real GDP per capita, $I$ is a set of variables that are commonly included in the regression, $M$ is the variable of particular interest and $Z$ is a set of variables chosen from a pool of variables and $\xi_{\mathrm{t}}$ is the white noise error term. In the context of our country-growth regression, $I$ or basic variable is the ratio of investment to GDP. Levine and Renelt (1992) have included the ratio of investment to GDP in their $I$ variables. More recently, Temple (1999) also argued that there exists a robust correlation between investment and growth. The $M$ variable is the variable of interest that is financial depth. The $Z$ variable are selected as follow: (i) the ratio of government expenditure on education to GDP (EDU), (ii) openness, which is calculated as (export + import) to GDP (OPE), and (iii) the ratio of Foreign Direct Investment to GDP.

As regard to the $Z$ variables, at the macroeconomic level, Levine and Renelt (1992) found in their study that trade liberalization and growth relations may occur through investment and trade openness may provide greater access to investment goods. Levine and Zervos (1998) showed that stock markets and banks provide different services, but stock market liquidity and banking development positively predict growth and capital accumulation. The results of the sensitivity analysis with autocorrelation correction are reported in Table $6^{7}$.

Table 6 . Results of sensitivity analysis with autocorrelation correction

\begin{tabular}{lccccc}
\hline $\begin{array}{c}\text { Variable } \\
\text { incorporated }\end{array}$ & $\begin{array}{c}\text { Coefficient of } \\
\text { focus variable }\end{array}$ & t-statistics & Adjusted-R ${ }^{2}$ & $\begin{array}{c}\text { Durbin-Watson } \\
\text { statistics }\end{array}$ & F-statistics \\
\hline Basic model & 0.126 & 6.061 & 0.724 & 2.020 & 30.667 \\
\hline EDU & 0.129 & 6.425 & 0.671 & 2.128 & 24.159 \\
\hline OPE & 0.139 & 7.252 & 0.730 & 1.974 & 31.613 \\
\hline FDI & 0.128 & 6.623 & 0.680 & 2.039 & 25.096 \\
\hline
\end{tabular}

\footnotetext{
${ }^{7}$ Study has used Cochrane-Orcutt iterative procedure to correct the autocorrelation problem in the models (see Gujarati 2003: 482-484).
} 
Form the Table 6 it is obvious that the positive coefficient of focus variable, that is, financial depth remains significant, no matter what kind of linear combination of the omitted variable is being incorporated in the model. Form these results it can be concluded that the initial estimates are robust and highly significant.

\section{Conclusions}

We examine the long-run relationship between banking sector liberalization and economic growth for Pakistan for the period 1971 to 2011. Estimation procedure starts with examining stationarity properties of the underlying time series data. ADF and PP unit root test results suggest that the variables are non-stationary at level but stationary at their first difference. Johansen co-integration test results show that banking sector development and economic growth are positively co-integrated in the long run and there is only one co-integrating vector, which indicates a stable long run relationship. These results were further confirmed when study performed a sensitivity analysis, which shows that the initial results are robust.

Our findings suggest that that the banking sector development indicator has a direct impact on real output. These strong findings may be attributed to the efficient allocation of resources by banks, along with the presence of an appropriate investment climate required to foster significant private investment and promote growth in the long run in Pakistan. Moreover, the econometric analysis shows that the other macroeconomic variables provide more proof in explaining the real per capita income in Pakistan. The level of investment exerts a positive and statistically significant impact on real per capita income in the long run. Government spending on health variable appear with the correct sign and is statistically significant for our basic model of long run analysis.

Thus, our analysis finds support for the core idea that banking sector liberalization stimulates faster economic growth. One of the most obvious implications of our results is that if Pakistan is to realize its target growth rate it needs to create a stable banking sector and economic climate conducive to investment. It follows from this that banking sector's development and policies designated to raise investment are a precondition for Pakistan's economic success.

Worldwide experience in developed and developing countries, including East and South Asia, gives examples of the policies needed to help stimulate a finance-led economic growth. Such policies require being adapted to Pakistan's specific situation and needs. This is what the study search for do. While the recommendations do not endow with all the answers to the tackle of accelerating comprehensive economic growth, they embrace the most critical (short and long term) actions necessary to remove main obstacles to faster wide-ranging growth in Pakistan at this time.

Further research recommendations are the collection of better quality and more extensive indicators of financial depth because M2 and bank deposits are not only indicators but other indicators for liberalization of banking sector such as market structure, interest rate spreads, market capitalization and liquidity, legal and regulatory frameworks, accounting practices and payments systems should be used in future research for crosscountry comparison. 


\section{References}

Adam, M. A. 2011. Financial openness induced growth and poverty reduction, The International Journal of Applied Economics and Finance 5(1): 75-86.

http://dx.doi.org/10.3923/ijaef.2011.75.86

Altunbas, Y.; Molyneux. P.; Murphy, N. B. 1994. Privatization, efficiency and public ownership in Turkey: an analysis of the banking industry 1991 to 1993, IEF Research Papers.

Aly, H. Y.; Grabowski, R.; Pasurka, C.; Rangan, N. 1990. Technical, scale, and allocative efficiencies in U.S. banking: an empirical investigation, The Review of Economics and Statistics 72: 211-18. http://dx.doi.org/10.2307/2109710

Arestis, P.; Demetriades, P.; Luintel, K. 2001. Financial development and growth: the role of stock markets, Journal of Money, Credit and Banking 30: 16-41. http://dx.doi.org/10.2307/2673870

Ataullah, A. T.; Cockerill, H. Le. 2004. Financial liberalization and bank efficiency: a comparative analysis of India and Pakistan, Applied Economics 36: 1915-1924.

http://dx.doi.org/10.1080/000368404200068638

Ayadi, O. F. 1996. Marketing of bank services, regulation, and bank profitability in an emerging banking system, African Review of Money, Finance and Banking 1/2: 107-119.

Berger, A. N.; Hunter, W. C.; Timme, S. G. 1993. The efficiency of financial institutions: a review and preview of research, past, present and future, Journal of Banking and Finance 17: 221-250. http://dx.doi.org/10.1016/0378-4266(93)90030-H

Burki, A. A.; Niazi, G. S. K. 2006. Impact of financial reforms on efficiency of state-owned, private and foreign banks in Pakistan, Working Paper. Centre for Management of Economic Research (CMER). 6-49.

Bumann, S.; Hermes, N.; Lensink, R. 2013. Financial liberalization and economic growth: a meta-analysis, Journal of International Money and Finance 33: 255-281.

http://dx.doi.org/10.1016/j.jimonfin.2012.11.013

Bouzid, A. 2012. McKinnon's complementarity hypothesis: empirical evidence for the Arab Maghrebean countries, The Romanian Economic Journal 14(44): 23-36.

Campos, N. F.; Karanasos, M. G.; Tan, B. 2012. Two to tangle: financial development, political instability and economic growth in Argentina, Journal of Banking and Finance 36(1): 290-304. http://dx.doi.org/10.1016/j.jbankfin.2011.07.011

Chang, C. E.; Hasan, I.; Hunter, W. C. 1998. Efficiency of multinational banks: an empirical investigation, Applied Financial Economics 8: 689-696. http://dx.doi.org/10.1080/096031098332727

Dickey, D. A.; Fuller, W. A. 1981. Likelihood ratio statistics for autoregressive time series with a unit root, Econometrica 49(4): 1057-1072. http://dx.doi.org/10.2307/1912517

Engle, R. F.; Granger, C. W. F. 1987. Co-integration and error correction: representation, estimation and testing, Econometrica 55(2): 251-276. http://dx.doi.org/10.2307/1913236

Goldsmith, R. 1969. Financial structure and development. New Haven: Yale University Press.

Greenwood, J.; Sanchez, J. M.; Wang, Ch. 2013. Quantifying the impact of financial development on economic development, Review of Economic Dynamics 16: 194-215.

http://dx.doi.org/10.1016/j.red.2012.07.003

Gujarati, D. N. 2003. Basic econometrics. New York, NY: McGraw-Hill Companies, Inc.

Hsueh, S. J.; Hu, Y. H.; Tu, C. H. 2013. Economic growth and financial development in Asian countries: a bootstrap panel Granger causality analysis, Economic Modelling 3: 294-301.

http://dx.doi.org/10.1016/j.econmod.2013.02.027

Hye, Q. M. A.; Wizarat, S. 2013. Impact of financial liberalization on economic growth: a case study of Pakistan, Asian Economic and Financial Review 3(2): 270-282. 
Johansen, S. 1988. Statistical analysis of co-integration vectors, Journal of Economic Dynamics and Control 12: 231-254. http://dx.doi.org/10.1016/0165-1889(88)90041-3

Johansen, S.; Juselius, K. 1990. Maximum likelihood estimation and inference on co-integration with applications to the demand for money, Oxford Bulletin of Economics and Statistics 52(2): 169-210. http://dx.doi.org/10.1111/j.1468-0084.1990.mp52002003.x

Khan, M. A.; Qayyum, A.; Sheikh, S. A. 2005. Financial development and economic growth: the case of Pakistan, Pakistan Development Review 44(4): 819-837.

Khan, M.; Senhadji, A. 2000. Financial development and economic growth: an overview, Working Paper. IMF.

King, R. G.; Levine, R. 1993a. Finance and growth: Schumpeter might be right, Quarterly Journal of Economics 108: 717-37. http://dx.doi.org/10.2307/2118406

King, R. G.; Levine, R. 1993b. Finance, entrepreneurship and growth: theory and evidence, Journal of Monetary Economics 32: 1-30. http://dx.doi.org/10.1016/0304-3932(93)90028-E

Leamer, E. E. 1985. Sensitivity analysis would help, American Economic Review 75(3): 308-313.

Levine, R. 1997. Financial development and economic growth: views and agenda, Journal of Economic Literature 35(2): 688-726.

Levine, R.; Renelt, D. 1992. A sensitivity analysis of cross-country growth regressions, American Economic Review 82(4): 942-63.

Levine, R.; Zervos, S. 1998. Stock markets, banks, and economic growth, American Economic Review 88(3): 537-558.

Levine, R.; Loayza, N.; Beck, T. 1999. Financial intermediation and growth: causality and causes, Working Paper No. 2059. World Bank, Washington DC.

McKinnon, R. I. 1973. Money and capital in economic development. Washington, DC: Brookings Institution.

Mendes, V.; Joao, R. 1999. Productive efficiency, technological change and productivity in Portuguese banking, Applied Financial Economics 9(5): 513-521.

http://dx.doi.org/10.1080/096031099332177

Narayan, P. K.; Narayan, S. 2013. The short-run relationship between the financial system and economic growth: new evidence from regional panels, International Review of Financial Analysis 29: 70-78. http://dx.doi.org/10.1016/j.irfa.2013.03.012

Neusser, K.; Kugler, M. 1998. Manufacturing growth and financial development: evidence from OECD countries, Review of Economics and Statistics 80: 638-646.

http://dx.doi.org/10.1162/003465398557726

Odhiambo, N. M. 2011. The impact of financial liberalization in developing countries: experiences from four SADC countries, Organization for Social Science Research in Eastern and Southern Africa (OSSREA). Addis Ababa.

Owusu, E. L.; Odhiambo, N. M. 2013. Financial liberalization and economic growth in Nigeria: an ARDL-bound testing approach, Journal of Economic Policy Reform 17(2): 164-177.

http://dx.doi.org/10.1080/17487870.2013.787803

Pagano, M. 1993. Financial markets and growth: an overview, European Economic Review 37: 613-22. http://dx.doi.org/10.1016/0014-2921(93)90051-B

Phillips, P. C. B.; Perron, P. P. 1988. Testing for a unit root in time series regression, Biometrika 75(2): 335-346. http://dx.doi.org/10.1093/biomet/75.2.335

Rousseau, P.; Watchel, P. 1998. Financial intermediation and economic performance: historical evidence from five industrial countries, Journal of Money, Credit, and Banking 30: 658-678. http://dx.doi.org/10.2307/2601123 
Schumpeter, J. 1911. The theory of economic development. Cambridge Harvard University Press. Shaw, E. S. 1973. Financial deepening in economic development. New York, NY: Oxford University Press.

Sulaiman, L. A.; Oke, M.O; Azeez, B. A. 2012. Effect of financial liberalization on economic growth in developing countries: the Nigerian experience, International Journal of Economics and Management Sciences 1(12): 16-28.

Temple, J. 1999. The new growth evidence, Journal of Economic Literature 37: 112-156. http://dx.doi.org/10.1257/jel.37.1.112

Tsuru, K. 2000. Finance and growth, Working Paper No. 228. Economics Department, OECD, Paris.

Waheed, A.; Younus, N. 2010. Effects of financial sector's development and financial sector's efficiency on economic growth: empirical evidence from developing and developed countries, International Journal of Economic Perspectives 4(2): 449-458.

$\mathrm{Xu}, \mathrm{Z}$. 2000. Financial development, investment and economic growth, Economic Inquiry 38(2): 331-344. http://dx.doi.org/10.1111/j.1465-7295.2000.tb00021.x

Najia SAQIB (Dr) is the Assistant Professor at College of Business, Prince Sultan University RiyadhSaudi Arabia. Her specializations in Quantitative Research in the field of Economics \& Finance with deep interest in social \& financial sector development, Macroeconomic Modeling, implication and implementation. She has several international publications in refereed journals and few published books at national level. 